\title{
EXPLANATORY ANALYSIS OF ANCILLARY REVENUES: CASE STUDY OF THREE EUROPEAN AIRLINES
}

This paper quantifies an impact of ancillary revenues on changes of airlines total revenues using the data of three European low-cost airlines during the period from 2006 to 2011. The analysis reveals that ancillary revenues are important in generating total revenues in a low cost airlines group in terms of dynamics and subsequent influence on profit/loss result. The research findings confirmed that ancillary revenues influenced changes of total revenues significantly achieving in prevailing cases double-digit percentage share in the changes of total revenues expressed as a whole. So, quantified impact of ancillary revenues dynamics on dynamic of total revenues is undoubtly important for overall dynamics of airlines total revenues. Our analysis based on quantitative approach of explanatory analysis also clearly identified ancillary revenues as pro-operational profit driver through its positive and not marginal impact on dynamics in total airlines revenues. This disclosure is in line with general assumption of considerable role of ancillary revenues in low cost airlines economics.

Keywords: Airlines, ancillary revenues, explanatory analysis, product, quality.

\section{Introduction and motivation}

Airlines economics is of special nature mainly due to derived demand for air services in passenger and cargo segment which makes it very fragile, risky and volatile. Moreover, airlines compete in fully liberal or gradually liberalizing markets, which lead to higher pressure on airlines costs and revenue management. Changes of airlines revenues are therefore partially externally given, although influence of endogenous drivers such as revenue management, product policy, pricing etc. ought not to be neglected in this context. Just these internal forces of airlines management decide about market success of airlines.

The concept of ancillary revenues is a part of broader product policy and price policy built on applied business model. The topic is intensively researched with regard to sharpening airlines competition as just ancillary revenues stemming from miscellaneous generators in product and price policy may create new sources of revenues and compensate drops in other revenues or cope with increase in costs. In airline industry ancillary revenue is any revenue generated by airlines out of air ticket sale going into airlines operational profit/loss. Ancillary revenues may be miscellaneous - charges for luggage, sales of food and beverage on aircraft board, seat assignment charge etc. - reflecting different approaches of airlines towards product offered to customers. Generally, four main categories of ancillary revenues are defined: a la carte product revenues generated as a part of flight or air travel, commission-based product generated through sales of specific services (hotel accommodation, car leasing etc.), revenues generated by frequent flyer programs (through sale of services by airline partners in frequent flyer programs schemes and revenues from advertisement placed on the aircraft board or on aircraft itself. Mixture of drivers which generate ancillary revenues is very unique within airlines' economics. In the aggregate, airlines implemented unique business models although we can meet in scientific literature some typological archetypes assigning the strong role of ancillary revenues to a low-cost airlines group. A causa de cy we have decided to investigate a role of airlines ancillary revenues in total revenue generation in airline industry in a more detail using methodology of explanatory analysis.

\section{Methodology and aim}

We aimed at confrontation of selected low cost airlines with regard to ancillary revenues generation and its determinative impact on total airlines revenues. Therefore, we worked with three low cost airlines in our analysis, (Ryanair, easyJet, Flybe) traditionally labelled as low cost carriers. As ancillary revenues of the airlines ought to be considered within overall airlines business concept, we exposed the airlines business models to qualitative and quantitative analysis using the works of Klophaus et al. [1], also Lohmann and Koo [2], Daft and Alberts [3] and

\footnotetext{
* Anna Tomova, Zdenka Strmiskova

Department of Air Transport, Faculty of Operation and Economics of Transport and Communications, University of Zilina, Slovakia,

E-mail: anna.tomova@fpedas.uniza.sk
} 


\begin{tabular}{|c|c|c|c|c|c|c|c|}
\hline & \multicolumn{3}{|c|}{ Fleet Composition } & \multicolumn{4}{c|}{ Network Design } \\
\cline { 2 - 8 } & $\begin{array}{c}\text { Number of } \\
\text { Aircraft Types }\end{array}$ & HHI Index & $\begin{array}{c}\text { The Most } \\
\text { Common } \\
\text { Aircraft Type } \\
\text { in \% }\end{array}$ & Transfer Flights & $\begin{array}{c}\text { Network } \\
\text { Concept }\end{array}$ & $\begin{array}{c}\text { Number of } \\
\text { Destinations }\end{array}$ & $\begin{array}{c}\text { Average } \\
\text { Distance of 5 } \\
\text { Top Airports to } \\
\text { the City Center }\end{array}$ \\
\hline Ryanair & 1 & 1.00 & 100 & No & point-to-point & 187 & $30 \mathrm{~km}$ \\
\hline easyJet & 2 & 0.8517 & 74 & Yes & hub and spoke & 118 & $12 \mathrm{~km}$ \\
\hline Flybe & 6 & n. a. & 68 & Yes & hub and spoke & 56 & $12 \mathrm{~km}$ \\
\hline
\end{tabular}

Source: Own investigation and computation based on [5], [6], [7].

HHI is Herfidahl-Hirschmann Index. n. a. = not available

Mason and Morrison [4]. Thus, motivated by methodologies of the above-mentioned authors we compiled available qualitative and quantitative descriptive characteristics of business models implemented by the airlines researched. They are gathered in Table 1.

As it can be seen in Table 1, there is no so strict convergence among the airlines investigated when we operate the abovementioned descriptive characteristics as a whole - the fact strongly opposing the textbook archetypes of low cost business model. Regarding fleet composition and network design only Ryanair gets near theoretical drivers of low-cost carrier letting the others be somewhere in the middle. For instance, Flybe, which was regarded generally as a low-cost carrier, records fleet structure characteristics more typical for full service carriers. Similarly, easyJet and Flybe operate hub and spoke system typical for a full service network carrier offering transfer flights for their passengers - again a feature typical for a clear full services concept of business model. Moreover, Flybe may be noted for its horizontal cooperation - again a fact attributable to full service network business model - as hybridizing airline blending features typical for both theoretical archetypes. Information contained in Table 1 shows yet that every airline business model driver relevant for business model analysis can be described by optional parameters and approaches which can be tackled by different authors differently and thus any conclusion about type of business models applied within airlines is highly influenced by methodology taken. Consequently, one airline may be denoted as low-cost by some authors while others may designate it as hybrid almost with prevailing features of full service network operation. Klophaus et al., for instance, deem that only Ryanair may be without any doubt indicated as a purely low-cost while easyJet is more a hybrid airline with still prevailing low-cost features and Flybe evinces like a more hybrid airline strongly converging by its business concept to full service carriers [1].

We searched the role of ancillary revenues of the airlines as a component present in different (i.e. unique) business models of three different (i.e. unique) airlines more or less coinciding with theoretical (and textbook only) assumption about low cost airline business model. Moreover, ancillary revenues of the airlines may have different structure resulting from different policy depending on the fact whether more bundled or more unbundled product policy is implemented within airline. As Table 2 depicts, there are not so significant differences in main components of ancillary revenues generated by airlines in the sample investigated, however, specific components of ancillary revenues may differ by their generators withal, for instance checked bag charge may contain charge for the $1^{\text {st }}$ baggage or not etc., for the $2^{\text {nd }}$ baggage or not etc.) [8]. Also, Table 2 informs only about main generators of airlines ancillary revenues which cannot fully provide necessary information on innovation in ancillary revenues generation [9].

As importance of ancillary revenues for airlines economics has been mentioned many times in scietific literature we decided to verify the statement by simple explanatory model. Thus, our research aim was to state in a quantitative way impact of ancillary revenue dynamic on dynamics of total airline revenues.

Overview of Main Generators of Airlines Ancillary Revenues

Table 2

\begin{tabular}{|c|c|c|c|c|c|c|}
\hline & F B on Board & Baggage Checking & Advertisement & $\begin{array}{c}\text { Frequent Flyer } \\
\text { Programs }\end{array}$ & Seat Assignment & $\begin{array}{c}\text { Credit Card } \\
\text { Payment }\end{array}$ \\
\hline Ryanair & + & + & + & - & + & - \\
\hline easyJet & + & + & + & + & - & - \\
\hline Flybe & + & + & + & + & + & + \\
\hline
\end{tabular}

Source: Own investigation based on [10], [11], [12] 


\begin{tabular}{|c|c|c|c|}
\hline \multirow{2}{*}{ Year/Airline } & \multicolumn{2}{|c|}{ Total revenues (of which ancillary revenues in \%) } \\
\cline { 2 - 4 } & Ryanair (in mil. EUR) & easyJet (in mil. GBP) & Flybe (in mil. GBP) \\
\hline \multirow{2}{*}{2006} & 1,693 & 1,620 & 513 \\
& $(15.31)$ & $(8.1)$ & $(12.48)$ \\
\hline \multirow{2}{*}{2007} & 2,237 & 1,797 & 536 \\
& $(16.18)$ & $(9.53)$ & $(12.23)$ \\
\hline \multirow{2}{*}{2008} & 2,713 & 2,363 & $(12.86)$ \\
\hline \multirow{2}{*}{2009} & $(17.99)$ & $(15.54)$ & 571 \\
& 2,941 & 2,667 & $(15.07)$ \\
\hline \multirow{2}{*}{2010} & $(20.32)$ & $(19.36)$ & $(16.61)$ \\
\hline \multirow{2}{*}{2011} & 2,988 & 2,973 & 615 \\
& $(22.20)$ & $(19.22)$ & $(16.95)$ \\
\hline
\end{tabular}

Source: [5], [6], [7]

To quantify the impact of ancillary revenues on airlines total revenues, we used explanatory analysis in the form of a dynamic additive model and subsequent quantification procedure as explained by Zalai et al. [13] which produced QAR.

QAR is a quantified impact of ancillary revenues generation on dynamics of total airline revenue.

The result of explanatory analysis we obtained is represented by quantified percentage impact of annual change in ancillary revenues on annual change of airlines total revenues tackled as $100 \%$ (QAR) (i.e. change of total revenues in \% as an integer) regardless of the specific case. As source data for computation we used annual reports of the airline companies obtaining in this way a dataset covering annual changes of the characteristic analyzed within the period from 2006 to 2011. Main input data in round numbers for analysis are contained in Table 3.

First glance into the input data reveals growing share of ancillary revenues in total revenues, however, not providing strict quantification of their impact on total revenues dynamics, which was exactly our research aim.

\section{Results}

Summarizing, we tried to reveal determinance of changes in ancillary revenues with regard to changes in total revenues and thus obtain an argument about quantitative significance of changes in ancillary revenues towards changes in total airlines revenue. We deem that our methodology enables to reveal more a role of ancillary revenues as pro-profit drivers through its role in increase of total revenues. Applying the standard procedure of explanatory analysis, we have got the research output contained in Table 4.

Although mutually diverse, in bulk the research outputs identify clearly strong determinative impact of changes in ancillary revenues on dynamics of total revenues achieving in majority of cases double-digit score. In all investigated cases our analysis also revealed the ancillary revenue changes as important pro-revenues and thus pro-profit driver. It can be documented, for instance, by Flybe result in 2007 when in spite of generation of loss ancillary revenues ensured $6.8 \%$ of the total increase in revenues by $4.4 \%$ on annual basis. Similarly, another Flybe result from 2009 suggests that change in ancillary revenues acted as crucial driver against overall decrease of total revenues keeping thus only slight drop in total revenues. So as Ryanair result quantifying determinative share of ancillary revenues in change of total revenues in 2010 at $151.9 \%$ means that other components of total revenues operated against significant positive impact of ancillary revenues on the total revenues value.

The outputs also showed that the share of ancillary revenues in total airline revenues need not express fully their impact on total revenues dynamics. That was a main reason to work just with an explanatory determinative analysis. Although having about $10-20 \%$ share in total revenues, ancillary revenues may reverse negative dynamics of other revenues components or, at least, significantly alleviate worsening dynamics of total revenue generation and thus produce more acceptable result for profit/ loss statement. The value of determinative impact of change in ancillary revenues on total revenues change exceeded the share of ancillary revenues in total revenues in majority of cases we investigated. This is the most significant result of our invstigation.

Deeper analysis of ancillary revenues as a driver for positive dynamics of total revenues would require work with data in a more detail which would enable to tackle also the role of separate internal components of ancillary revenues. Such approach could answer how these components influence the final shape of dynamics of ancillary revenues and their impact on total revenues as well and quality of air transportation perceived 


\begin{tabular}{|c|c|c|c|c|c|}
\hline & \multicolumn{5}{|c|}{ Year } \\
\hline & 2007 & 2008 & 2009 & 2010 & 2011 \\
\hline & \multicolumn{5}{|c|}{ Ryanair } \\
\hline Annual Change of Total Revenues in \% (regarded as $100 \%$ ) & 32,1 & 1,3 & 8,4 & 1,6 & 21,5 \\
\hline $\begin{array}{l}\text { Explanatory Determinative Share of Ancillary Revenues of } 100 \% \text { Change in Total } \\
\text { Revenues (QAR) }\end{array}$ & 20.0 & 29.5 & 54.52 & 151.9 & 21.4 \\
\hline \multirow[t]{2}{*}{ Profit/Loss Recorded (Ancillary Revenues as Pro-Revenue Driver in Profit Generation) } & $\begin{array}{l}P \\
\checkmark\end{array}$ & $\begin{array}{l}P \\
\checkmark\end{array}$ & $\begin{array}{l}P \\
\checkmark\end{array}$ & $\begin{array}{l}P \\
\checkmark\end{array}$ & $\begin{array}{l}P \\
\checkmark\end{array}$ \\
\hline & \multicolumn{5}{|c|}{ easyJet } \\
\hline Annual Change of Total Revenues in \% (regarded as $100 \%$ ) & 11.0 & 31.5 & 12.9 & 11.5 & 16.10 \\
\hline $\begin{array}{l}\text { Explanatory Determinative Share of Ancillary Revenues of } 100 \% \text { Change in Total } \\
\text { Revenues (QAR) }\end{array}$ & 26.3 & 56.2 & 60.9 & 17.9 & 89.0 \\
\hline \multirow[t]{2}{*}{ Profit/Loss Recorded (Ancillary Revenues as Pro-Revenues Driver in Profit Generation) } & $\begin{array}{l}P \\
\checkmark\end{array}$ & $\begin{array}{l}P \\
\checkmark\end{array}$ & $\begin{array}{l}P \\
\checkmark\end{array}$ & $\begin{array}{l}P \\
\checkmark\end{array}$ & $\begin{array}{l}P \\
\checkmark\end{array}$ \\
\hline & \multicolumn{5}{|c|}{ Flybe } \\
\hline Annual Change of Total Revenues in \% (regarded as $100 \%$ ) & 4.6 & 6.8 & -0.33 & 4.4 & 3.3 \\
\hline $\begin{array}{l}\text { Explanatory Determinative Share of Ancillary Revenues of } 100 \% \text { Change in Total } \\
\text { Revenues (QAR) }\end{array}$ & 6.8 & 23.2 & 652,6 & 56.6 & 27.8 \\
\hline Profit/Loss Recorded (Ancillary Revenues as Pro-Revenues Driver in Profit Generation) & $\begin{array}{l}\mathrm{L} \\
\checkmark\end{array}$ & $\begin{array}{l}P \\
\checkmark\end{array}$ & $\begin{array}{l}P \\
\checkmark\end{array}$ & $\begin{array}{l}P \\
\checkmark\end{array}$ & $\begin{array}{l}P \\
\checkmark\end{array}$ \\
\hline
\end{tabular}

Source: Own. Results are round numbers.

(When in italic, the determinative quantitative effect acted against the final result of change in total revenues achieved; $\checkmark$ indicates situations in which ancillary revenues operated as a pro-revenues driver.)

by customers [10]. Consequently, the shape of product policy towards more sophisticated innovations could be researched more to highlight product/price strategy followed by airlines and its role in the battle of competition in down-stream markets within air transportation industry.

\section{Conclusions and future research ideas}

Our research has confirmed in a quantitative way that lowcost airlines at the time are much more dependent on earning generated out of traditional ticket sales though ancillary revenues streams and the tendency is unambiguous and percieved by passengers as a distinguishing feature of low cost airlines [11] and [13]. Based on case studies of three airlines traditionally ranked among leading European low-cost carriers (Ryanair, easyJet and Flybe) we have provided a quantitative proof about significance of ancillary revenues in total revenues dynamics in the low-cost airline industry using tools of explanatory determinative analysis applied on simple additive revenues model. The fact of increasing role of ancillary revenues has been mentioned verbally many times in numerous scientific literature, however, our approach has focused on achieving quantitative result in a different way not relying only on the 'growing share of ancillary revenues in total revenues' argument. Resulting from our findings, value of determinative impact of change in ancillary revenues on total revenues change exceeded the share of ancillary revenues in total revenues in majority of cases we investigated. Our methodology presented here may be used on a broader list of airlines encompassing also full service network airlines. It can also help to understand more the nature of different ancillary revenues within different product and price policies of airlines. Such approach could contribute to reveal strategies of ancillary revenues applied in airlines - a question that may be different not only among airlines business models but also among world regions as well.

\section{Acknowledgement}

The work on this paper has been supported by the grant scheme of VEGA 1/350/12. 


\section{References}

[1] KLOPHAUS et al.: Low Cost Carriers Going Hybrid: Evidence from Europe. J. of Air Transport Management 23, 2012 ISSN -09696997, pp. 54-58

[2] LOHMAnN, G., KOO, T. T. R.: The Airlines Business Model Spectrum. J. of Air Transport Management, 7, 2012, ISSN -09696997, available online http://dx.doi.org/ 10.1016/j.jairtraman.2012.10.005

[3] DAFT, J., ALBERS, S.: A Conceptual Framework for Measuring Airline Business Model Convergence. Working Paper 110, 2012, University of Cologne

[4] MASON, K. J., MORRISON, W. G.: Towards a Means of Consistently Comparing Airline Business Models with an Application to the 'Low Cost' Airline Sector. Research in Transportation Economics 24, 2008, pp. 75-84

[5] Annual reports of Ryanair

[6] Annual reports of Flybe

[7] Annual Reports of easyJet

[8] BARONE, J. G. et al.: Baggage Fees and Airline Performance: A Case Study of Initial Investor Misperception. J. of the Transportation Research Forum, vol. 51, No. 1 (Spring 2012), pp. 5-18 Transportation Research Forum

[9] GARROW, L. A. et al.: Assessment of Product Debundling Trends in the US Airline Industry: Customer Service and Public Policy Implications. Transportation Research Part A 46, 2012, ISSN: 0965-8564 p. 255-268

[10] O' CONNELL, J. F., WILLIAMS, G.: Passengers' Perceptions of Low Cost Airlines and Full Service Carriers - A Case Study Involving Ryanair, Aer Lingus, Air Asia and Malaysia Airlines, Air Transport Group, 2008

[11] O 'CONNEL, J. F., WARNOCK-SMITH, D.: An Investigation into Preference and Acceptance Levels of Airline Ancillary Revenues. J. of Air Transport Management 33, 2013, ISSN -09696997, pp. 12-21

[12] ZALAI, K. et al.: Financial - Economic Analysis of Enterprise - the 8 $^{\text {th }}$ edition (in Slovak), 2013. ISBN 9788089393800

[13] WITTMER, A., ROWLEY, E.: Customer Value of Purchasable Supplementary Services: The Case of a European Full Network Carrier's Economy Class. J. of Air Transport Management, in press 2013, pp. 1-7. 